\title{
EXPLORING THE POTENTIAL OF FACEBOOK FOR BLENDED LEARNING
}

\author{
Patrisius Istiarto Djiwandono \\ patrisius.istiarto@machung.ac.id \\ English Letters Department, Faculty of Language and Arts, \\ Machung University, Malang
}

\begin{abstract}
The paper reports a small-scale exploratory research into the potential of Facebook for blended learning. It sets out to find answers to two research objectives: (1) ) identify the learners' opinions about the use of Facebook as a means of learning reading and job interview in English, and (2) determine the effect of blended learning on the learners' mastery of new vocabulary. Twenty-five freshmen students of class 2008 who were taking English class at Ma Chung University were taken as the respondents. After a pre-test was administered to them to identify their initial vocabulary mastery, an online task was assigned to them. The task required them to learn interview techniques, upload their own interview session, and read texts. A face-to-face interaction followed to deal with difficulties and clarify some issues. A post-test measuring their vocabulary growth and questionnaires to identify their opinions were then given at the end of the experiment. The result shows that while gaining significantly higher mastery of new words, the learners expressed different opinions on the use of Facebook as a means of blended learning. The majority felt that face-to-face interaction still needs to accompany the online session to clear up some difficulties and misunderstanding during the online session, while a few others opted for exclusively online session because of its efficiency and higher participation rate by passive learners.
\end{abstract}

Key words: Facebook, blended learning, vocabulary mastery, face-to-face interaction 


\begin{abstract}
Abstrak: Studi ini menggali potensi Facebook dalam skema BlendedLearning. Tujuannya adalah (1) mengenali pendapat para pemelajar tentang Facebook sebagai media belajar membaca bahasa Inggris dan melakukan wawancara bahasa Inggris, dan (2) menentukan dampak Blended Learning terhadap penguasaan kosa kata bahasa Inggris. Dua puluh lima mahasiswa yang sedang berkuliah Bahasa Inggris di Universitas Ma Chung diambil sebagai responden. Setelah pre-tes Vocabulary, mereka mengikuti empat kali sesi Blended Learning. Dalam kelompok, mereka menyajikan teks bacaan yang sudah dibaca melalui fasilitas Notes di Facebook, dan mengunduh sesi wawancaranya ke Facebook. Teks bacaan dan wawancara itu kemudian dibahas oleh kelompok lain melalui Facebook. Mereka saling bertukar isi dan kosa kata baru melalui kegiatan ini. Sesi tatap muka dilakukan setelah sesi online selesai untuk memperjelas beberapa hal dan menyelesaikan masalah yang timbul. Setelah itu post-test diberikan. Hasil menunjukkan bahwa sekalipun terjadi peningkatan penguasaan kosa kata, para mahasiswa mempunyai pendapat yang berbeda tentang perlunya tatap muka dalam skema Blended Learning ini. Yang mendukung sesi Facebook murni mengemukakan efisiensi waktu dan kesempatan yang lebih banyak untuk mahasiswa yang pasif untuk berpartisipasi. Yang mendukung tatap muka mengutarakan pentingnya interaksi luar jaringan (offline) untuk memperjelas beberapa poin dalam sesi online. Dalam pembahasan disinggung implikasi temuan ini untuk ranah praktis pembelajaran Blended Learning.
\end{abstract}

Kata kunci: Facebook, blended learning, penguasaan kosa kata, interaksi tatap muka

\title{
INTRODUCTION
}

The rapid advances of information technology open up a vast possibility of enhancing language teaching. It is becoming easier to overcome factors that once impeded the effectiveness and efficiency of classroom language learning. Information technology, particularly the Internet, offers teaching aids that go beyond the confinement of the classroom walls and fixed learning schedules. The advent of sophisticated technologies in computer and the Web has made it possible to run a blended learning, which is the combination of traditional classroom teaching and online learning.

This paper reports a small-scale exploratory study of blended learning through Facebook, and highlights the facilities on Facebook that may be of 
highly valuable language learning tools in blended learning. The paper also discusses possible caveats that language educators should treat with caution when using Facebook as a means for running blended learning.

\section{LITERATURE REVIEW}

Quite a number of scholars in the area of education have proposed definitions of blended learning. Blended learning, according to Singh and Reed (2001), is a technique that utilizes multiple delivery modes to optimize the learning outcome and at the same time maintaining cost-efficiency of the program. Valiathan (2002) maintains that blended learning is a blend of activities, including conventional face-to-face sessions, self-paced learning, and e-learning. Likewise, Finn and Bucceri (2004) stated that it integrates various learning methods, technologies, and ways of delivering the lessons to adapt to different aspects of communication, knowledge sharing, and needs for information. Blended-learning is simply defined as "courses that combine face-to-face classroom instruction with online learning and reduced classroom contact hours" (Dziuban, Hartman and Moskal, 2004, p.2). The obvious strength of blended-learning approach lies in its flexibility and the complementary nature of each of its elements. The online learning compensates for the limited time of instruction, space constraint, and rigid learning procedures that typically characterizes face-to-face instruction (Kengwee and Kidd, 2010), while face-to-face interaction, in turn, maintains the sense of genuine human interaction between teachers and learners that oftentimes is absent during online learning.

Closely related to the notion of blended learning is online learning.. Thus, in a similar vein, Khan (1997) defines online learning as the act of using Internet to obtain learning materials, and to interact with classmates and teachers so that the students can develop from that experience. Meanwhile, the present young generation of learners enjoys a myriad of online social networks that proliferate on the Internet. Facebook, one of such online networks, provides the users with increasingly complete facilities that cater for a wide range of personal interests. With such niceties that it provides, it is very easy to tap its potentials for blended learning. Salaway, Caruso and Nelson (2008) report that of 27,317 students in a large number of American universities and colleges use Facebook on a daily basis to keep in touch with others. Ausburn (2004) maintains that blended learning appeals highly to adult learners because it allows options, personalization, self-direction, variety, and learning community. These are exactly the features 
that are offered by today's most popular Social Networking Sites (SNS), such as Friendster or Facebook. It is not surprising, therefore, to see how well the SNS can be adapted to fit into adult learning needs. While studies on the impact of online learning on teaching have been growing in number (see Boyle et al., 2003; Cameron, 2003, Carroll, 2003, and Cottrell and Robinson, 2003), an investigation into the Facebook's potential for teaching and learning has yet to be carried out. Blattner and Fiori (2009) argue that Facebook is capable of building a sense of community among its users and promoting socio pragmatic competence. In Indonesia, Sari (2014) explored the usefulness of Facebook as a tool in Blended Learning Module and listed several helpful features of Facebook, which include free accounts, facilities for group discussion, and the openness of all posts and comments to public, thus facilitating exchanges of ideas among the members.

A study that identified students' opinions of Facebook as a means of learning was done by Kabilan et al (2010). They found that the majority of 300 undergraduate students believe that Facebook could be used as a tool in an online environment to assist students in their English learning. PromnitsHayashi (2011) reports a study of Facebook use among lower proficiency students, and states that Facebook raises learning motivation, and brings students closer to each other in teamwork, and is overall a very beneficial tool for learning. A more specific study that probed deeper into the facilities on Facebook was done by Alias et al. (2012). They found that the facility of Facebook notes increases the use of language learning strategies among students who were taught those strategies through Facebook notes. However, Facebook notes did not significantly raise their academic writing performance.

\section{METHODS}

\section{A. Research objectives}

The study aims to find out (1) the learners' opinions about the use of Facebook as a means of learning reading and job interview in English, and (2) the effect of blended learning on the learners' mastery of new vocabulary.

\section{B. Research design}

The study was carried out in a descriptive framework. It aimed to describe the students' current opinions about the advantages and disadvantages of Facebook in English language learning. It can also be called 
a case study since it focused on a single unit of class and investigated the class to some depth by means of tests and questionnaires. To the extent that it combined an analysis of qualitative data for the first research problem and quantitative data for the second, it used a mixed method design. As far as the second research problem is concerned, the study used a one-group-pretestposttest design.

\section{The respondents}

Twenty-five freshmen students of class 2008 who were taking English class from the writer at Ma Chung University were taken as respondents of the research. Their English proficiency was determined by International TOEIC test and, with the mean score of 596, they were estimated to be at the intermediate level. According to a training standard for professionals (http://www.nelson-aviation.co.nz/ ${ }^{\sim}$ downloads/TOEIC_Equivalence_Table s.pdf), students with the average score of 596 are able to carry out meaningful conversation and discussion at meetings albeit with some errors. Likewise, with reference to the six-level of CEFR (Common European Framework of Reference for Languages), ETS (https://www.etsglobal.org/ content/download/890/13127/version/2/file/TOEIC+CEFR+Mapping+Fl yer-MAR338-LR.pdf) classifies these students as independent users under level B1 - B2.

The tasks for the respondents take in the form of a pre-test measuring the students' initial vocabulary mastery prior to the blended learning. The instrument was in the form of 30-item short answer items where the respondents must write down the translation of some important, highfrequent vocabulary items taken from the field of business. The words in the test were selected by the lecturer himself on the basis of his teaching experience and a brief consultation with a lecturer from business management.

After the test, the blended learning started. The main objectives of the course were reading comprehension and interview preparation. They were taught how to gain main ideas and other detailed information from texts, and also some expressions for answering an interview.

The students were instructed to form groups of five. Each group was asked to find a video on job interviews from YouTube, and posted the videos on their Facebook pages. Second, based on the video, they had to record a simulated job interview of their own, and uploaded the recorded simulations into their Facebook pages. Then, they had to find texts on business management, read the texts, provided a glossary of new words for the text, 
and upload them onto their Facebook. They were encouraged to learn from the other groups' uploaded videos and texts.

The blended learning spanned four classroom sessions, each lasting 100 minutes. In each of the sessions, fifteen to twenty minutes were used for conventional teaching mode in the classroom, during which the tasks were explained to the students; the remaining time was used for online learning where the students accessed the learning materials through their Facebook pages in computer laboratories or from their laptops.

The reading of texts, learning of new vocabulary and learning fromuploaded interviews were done in this fashion. The lecturer conducted the session from his Facebook pages, asking questions and helping students' with problems by utilizing the chat and note facilities. Fifteen minutes before the end, the class convened again to discuss problems that arose during the online session.

By the beginning of the fourth session, all groups had uploaded their recorded interviews on their Facebook accounts. That was the beginning of the students' exchanges of ideas and learning from others, most of which took place online. The lecturer again gave written feedback from Facebook as well. At the end of the course, a post-test to measure their vocabulary mastery was given.

D. Data collection

To attain the first research objective, the data that were in the form of the students' opinions were collected by means of questionnaires, while the second objective was attained by comparing the pre-test and post-test scores.

\section{FINDINGS}

The table below shows the learners' opinions, stated in percentage, about the extent of effectiveness of each learning act in the blended learning: 
Table 1. Learners' opinions about the effectiveness of some instructional acts in online learning $(\mathrm{N}=25)$

\begin{tabular}{llllll}
\hline & $\begin{array}{l}\text { Uploading } \\
\text { materials }\end{array}$ & $\begin{array}{l}\text { Learning } \\
\text { from } \\
\text { others' } \\
\text { works }\end{array}$ & $\begin{array}{l}\text { Learning } \\
\text { from } \\
\text { downloaded } \\
\text { videos }\end{array}$ & $\begin{array}{l}\text { Receiving the } \\
\text { lecturer's } \\
\text { instructions }\end{array}$ & $\begin{array}{l}\text { Receiving } \\
\text { lecturer's } \\
\text { guidance }\end{array}$ \\
\hline $\begin{array}{l}\text { Effective } \\
\begin{array}{l}\text { Moderately } \\
\text { effective }\end{array}\end{array}$ & 32 & 56 & 40 & 40 & 44 \\
$\begin{array}{l}\text { Not } \\
\text { effective }\end{array}$ & 52 & 36 & 52 & 56 & 36 \\
\hline
\end{tabular}

The table below indicates the percentages of the learners with their opinions about the importance of F2F (face-to-face) interaction:

Table 2. Learners' opinions on the necessity of F2F interaction $(\mathrm{N}=25)$

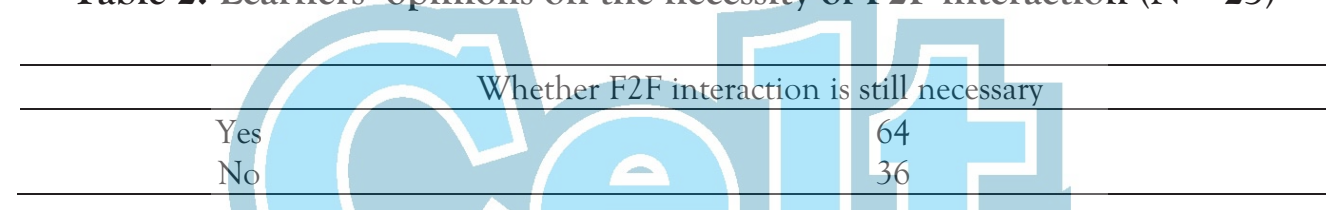

It is interesting to note that the majority of the learners (64\%) still consider F2F important in their learning process. Some of their most frequent written responses about the need for F2F are summed up below:

- F2F is needed to clarify some unclear explanations during the online mode.

- F2F clears up misunderstanding that may happen between the students and the lecturer.

- $\quad$ F2F provides more direct and clearer feedback for the students.

- F2F tackles problems which cannot be dealt with through online learning.

- F2F allows the students to know the lecture better.

In contrast, those who see F2F as no longer a necessary element also put forward their arguments. Some are the following:

- The online session is more efficient in terms of time and cost. 
22 Celt, Volume 15, Number 1, July 2015, pp. 15-30

- The online session allows shy students to come up confidently with answers or opinions.

- The online session adds a variety of activities to what otherwise is a boring class.

- The online session can be started without having to wait for latecomers.

As for the second research objective, the SPSS analysis of the pre and post-test scores generated the following tables:

Table 3. The descriptive statistics of the students' vocabulary scores

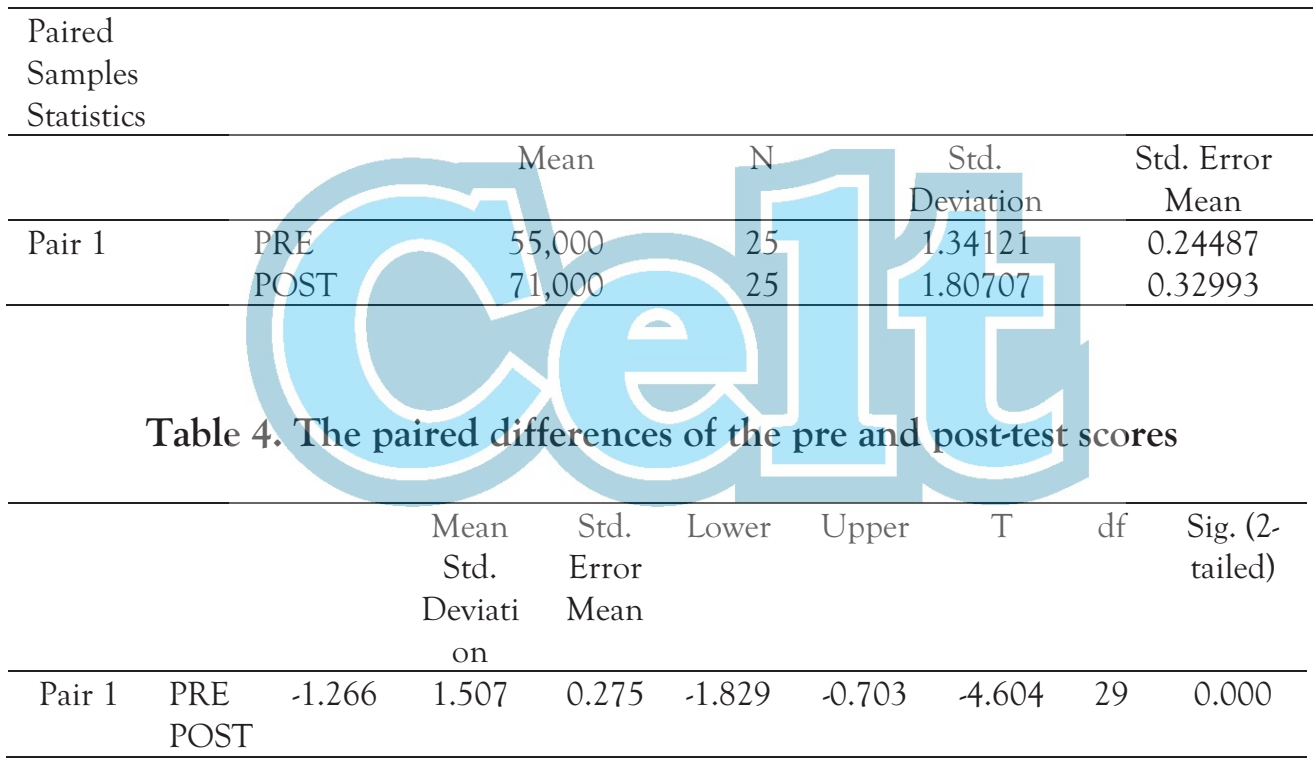

With $p<0.05$ as the last column of the table above shows, it is clearly shown that the scores are significantly different. The learners' mastery of vocabulary apparently improved after the blended learning.

\section{DISCUSSION}

As Table 1 suggests, Facebook seems to provide significant functionality for learning from peers' works and receiving online guidance from the lecturer. The learners may have found the Notes feature on 
Facebook helpful for their mutual learning. They thought, however, that receiving lecturer's guidance was slightly less effective than learning from each other's notes since the guidance, which was delivered through the chatting facility, was very much dependent on the Internet connection speed.

Most of them also regarded uploading materials, learning from downloaded videos and receiving the lecturer's instructions moderately effective on Facebook. Quite possibly this can be attributed to the reliance on Internet connection which determined the smooth execution of those learning acts. In peak hours at the university, the Internet connection slowed down a little and this may have interfered with the uploading, learning from downloaded videos, and receiving the lecturer's instructions.

\section{THE GAIN IN VOCABULARY MASTERY}

The finding showed a significant gain in the students' mastery of new words. With limited number of blended learning, it is probably too hasty to conclude that the new learning method contributed greatly to their improved mastery of new words. Still, it sounds reasonable to offer explanation as to why the students were able to increase their vocabulary mastery.

One of the factors may be the novelty of learned items. At the end of the four blended learning sessions, the students might still have remembered quite well the new vocabulary taught in the first session. As a result, when tested on more or less the same words they could retrieve the words easily and scored well.

Another factor that may account for this increase is motivation. At least one study by Farshi and Mohammadi (2013) investigated the role of podcasts in successful vocabulary learning by 30 Iranian students. They came to the conclusion that the use of podcasts heightened the students' motivation to learn, which in turn promoted their effort in learning vocabulary. By the same token, students in this present study may have received a boost of motivation when engaged in a novel technique through a popular online social media. Because they were highly motivated, they were willing to spend extra hours and efforts to learn the materials. As a result, they were able to perform better in the vocabulary post-test.

A similar aspect of my study and Farshi and Mohammadi's above is the use of modern technology in the learning context. In a way, their 
podcasts share something in common with Facebook, with both being accessible from anywhere and anytime provided the Internet connection is reliable. So, the notion that modern information technology contributes to the success of language learning seems to be an increasingly tenable idea.

Having discussed the two contributing factors above, the writer does not rule out the possibility of the test being not very reliable for measuring the students' achievement over the four sessions. An unreliable test may produce haphazard results that may accidentally indicate an increase. Being a teacher-made test, admittedly it did not undergo thorough procedures for establishing reliability, and thus any finding that stemmed from its use should be interpreted with caution.

\section{THE LEARNING ACTIVITIES}

Laurillard (as cited in Littlejohn and Pegler, 2007, p. 96) puts forward five major activities in blended learning, namely assimilative, adaptive, communicative, productive, and experiential. In assimilative activity, the learners comprehend written or oral discourse. In adaptive, they make the learning environment change or adapt to their input. In communicative, they engage in discussion with their peers or with the lecturer on a certain learning issue. In productive, they generate something by using the target language. In experiential activity, they engage in a problem solving situation. The online mode through Facebook provided tools that fit into most of those activities. Thus, the text and video viewer are tools for assimilative learning activity. The chat on Facebook gives ample opportunities for communicative activities. The uploading facility is clearly a tool for productive activity, and their simulated interviews are very much experiential activity. Only adaptive activity was not utilized fully in the project. Had there been more time to carry out interactive activity where the execution of a task and the feedback was done online, the adaptive feature would have been fully utilized.

One of the supporting features that prove to be most effective for learning is the ability to review and repeat the learning model presented on the online media. A study by Warnecke and Pearson (2011) found that most of their respondents derive great help in their learning of consultation skill from repeating and reviewing a model presented on their e-learning scheme. 


\section{THE NEED FOR F2F INTERACTION}

The finding above that most of the learners still deem F2F as an indispensable element is in line with Yamada's (2009) finding. He found that even when engaging in online communication, the students feel that image and voice promote higher awareness of natural communication, while textonly interaction raises higher grammatical correctness. When they see that the interlocutors are present in the form of image and voice, they are prompted to perform self-corrections, an act that in turn enhances their learning. This finds support in Littlejohn and Pegler (2007, p. 91), who contend that "the free flow of face-to-face, synchronous communication may be an effective way of expressing ideas and getting fast feedback." Indeed, as Dziuban, Hartman and Moskal (2004) found form their study, blended learning comes as an effective means for maintaining the face-to-face interaction.

A recent study by Stoltenkamp, Kabaka, and Braaf (2014) highlights the necessity for face-to-face interaction among participants who have been engaged in online learning. Indeed, their argument accords with some the students' opinions that face-to-face interaction is vital for resolving breakdown in communication and for enhancing clarity.

Sometimes problems that arose during the online session can be more effectively tackled in offline sessions. These range from slow Internet connection to team members' poor cooperation. What was most frequently found during my blended learning sessions was slow Internet connection and students' difficulty in understanding a few parts of the instruction. As far as these issues are concerned, no solutions can be more practical and effective than a face-to-face interaction with the lecturer to clear the misunderstanding and resolve the technical difficulties.

\section{THE NEED FOR EXCLUSIVELY ONLINE SESSIONS}

In contrast to students who thought that F2F is still necessary, some other students would like to have exclusively online sessions. The reasons they mentioned include cost and time efficiency, variation in learning activities, and greater opportunities for reserved students to participate more actively. Apparently, these students were turned off by monotonous and teacher-centered lesson in a classroom. They were also not very tolerant with tardiness and would like to have the course start right away without waiting for or getting interrupted by latecomers. More importantly, these are 
students who felt inhibited by the setting of a regular classroom where one's attitude and performance is very much subjected to the observation of others. Indeed, a small-scale study that I conducted last semester revealed that some students did participate more actively when they were allowed to have their online sessions where they had their own space with only a few of close friends. They became a little more engaged although they still came up with a few mistakes which their peers and their lecturer corrected later.

\section{IMPLICATIONS FOR TEACHING}

The study has revealed that Blended Learning through Facebook harnesses the potential for a more enriching, varied, and adjustable language instruction. It promotes flexibility in terms of the lesson materials and time and place for studying. A teacher can use Blended Learning scheme to incorporate the elements of asynchronous learning, access to wider learning resources, increased online interaction among the students, and more conducive environment for those who are otherwise reserved and passive in a conventional classroom. Still, the element of face-to-face interaction is a factor that a teacher should not neglect. Having enjoyed the advantages of online session, the teacher should still be prepared for the offline session where students typically come up with questions and problems that cannot be resolved in online fashion. A good teacher can skillfully manage the offline interaction so students will come out feeling more enthusiastic, more motivated, and not get disheartened by all difficulties they face during the online session.

A very good and observant teacher can even identify features of tasks that are better assigned online and tasks that require the teacher's physical presence. Interview, for example, is a task whose feedback to students is likely to be more efficacious and effective when delivered in a face-to-face interaction. Writing, on the other hand, can be assigned fully online because the written feedback, unlike in speaking, can still be clear without a physical representation of the teacher. What constitutes ideal tasks for online and offline session is open to further investigation.

\section{SOME CAVEATS}

The foregoing discussion has revealed that blended learning can offer to language teaching. Yet, some caveats need to be made. The foremost 
supporting element that is crucial is obviously the Internet connection. If this connection is not reliable, the online session will be rendered less effective. Thus, it is necessary that a school ensures that the Internet connection runs reliably well to support downloading, uploading, and many other activities that hinges on the speed and smoothness of the connection. This is in line with what Aguinaldo (2013) states as the supporting factors for a blended-learning scheme, which include technological sustainability, financial sustainability and social sustainability. The first of these, technological sustainability, means that reliable equipment like computers, servers, and Internet connection must be provided to ensure smooth operation of blended-learning.

Teachers' familiarity and skill in using Facebook as a means of learning also plays an important role. Effective blended learning assumes that the teacher as well as the learners needs to adapt at utilizing the apps that Facebook provides. As Sari (2014) argues, a blended learning scheme necessitates a change of the teachers' mindset and skills in operating and making use of a variety of facilities that popular social media provide. Needles to say that without such abilities, the various features that Facebook provides will be left largely untapped.

Finally, it is to be noted that online learning, at its current stage of development, still cannot fully replace the learning atmosphere and sense of communality induced by conventional face-to-face session. Therefore, serious efforts need to be made to ensure that the face-to-face interaction among the participants works effectively to promote learning.

\section{CONCLUSION}

The research sets out to investigate the potential of Facebook for blended learning. It aims to find answers to two research objectives, namely to identify the learners' opinions about the use of Facebook as a means of learning reading comprehension and job interview in English, and to determine the effect of blended learning on the learners' mastery of new vocabulary. Twenty-five freshmen students were given a series of tasks of learning interview techniques and reading comprehension. Part of the session was conducted using Note and chat facilities in Facebook. Another part of the lesson consisted of face-to-face interaction.

The results indicates a significant gain on the vocabulary learning, and points out some areas of concern that needs to be addressed adequately in a blended-learning program. The learners' opinions vary, with the majority 
of them still express the need for face-to-face interaction. Those who wish to have more online session, however, argues that the session can promote more efficiency and more active participation from otherwise passive learners in a traditional classroom setting. Several words of caveat are then presented, addressing the need to maintain face-to-face interaction and to equip teachers with practical skills of utilizing online facilities to make learning possible.The finding, admittedly, was generated by a non-experimental design with a treatment that lasted a relatively short time. Further research in the same line of enquiry should arrange for a longer time and a more rigorous design that allows for more tenable findings about the power of blended learning.

\section{REFERENCES}

Aguinaldo, B. E. (2013). Implementing blended learning in an impoverished academic institution using a Bricolage Approach Model. International Journal of Information and Education Technology, 3 (2), 211-216.

Alias, A.A, Manan, N.A.A, Yusof, J \& Pandian, A. (2012). The use of Facebook as language learning strategy (LLS) training tool on college students' LLS use and academic writing performance. Procedia-Social and Behavioral Sciences 67, 36-48.

Ausburn, L. J. (2004). Course design elements most valued by adult learners in blended online education environments: An American perspective. Educational Media International, 41 (4), 327-337.

Blattner, G, \& Fiori, M. (2009) Facebook in the language classroom: Promises and possibilities. International Journal of Instructional Technology $\&$ Distance Learning. Retrieved January 18, 2014 from www.itdl.org/journal/Jan_09/article02.htm

Boyle, T, Bradley, C, Chalk, P, Jones, R \& Pickard, P. (2003). Using blended learning to improve student success rates in learning to program. Journal of Educational Media 28, (2-3), 165-178.

Cameron, B. (2003). The effectiveness of simulation in a hybrid and online networking course. TechTrends, 47 (5), 18-21.

Carroll, B. (2003). Going hybrid: online course components increase flexibility of on-campus courses. Online Classroom. 
Cottrell, D.M, \& Robinson, R.A. (2003). Blended learning in an accounting course. The Quarterly Review of Distance Education, 4 (3), 261-269.

Dziuban, C. D, Hartman, J. L. \& Moskal, P. D. (2004). Blended learning. EDUCAUSE Center for Applied Research, 7. Retrieved May 20, 2014 from http://net.educause.edu/ir/library/pdf/ERB0407.pdf

Farshi, N, \& Mohammadi, Z. (2013). Use of podcasts in effective teaching of vocabulary: learners' attitudes, motivations and limitations. Theory and Practice in Language Studies, 3 (8), 1381-1386.

Finn, A., and Bucceri, M. (2004). A case study approach to blended learning. Los Angeles: Centra Software.

Kabilan, M.K, Ahmad, N, \& Abidin, M.J. (2010). Facebook: An online environment for learning of English in institutions of higher education. The Internet and Higher Education 13 (4), 179-187.

Kengwee, J, \& Kidd, T.T. (2010). Towards best practices in online learning and teaching in Higher Education. MERLOT Journal of Online Learning and Teaching, 6 (2). Retrieved July 3, 2014 from http://jolt. merlot.org/vol6no2/keengwe_0610.htm

Khan (1997). Web based instruction: What is it and why is it? In Web based instruction. Englewood Cliffs, New Jersey: Educational Technology Publications.

Littlejohn, A., \& Pegler, C. (2007). Preparing for blended e-learning. London: Routledge.

Mapping the TOEIC and TOEIC bridge tests on the Common European Framework of References for Languages. (n.d). Retrieved December 1, 2014 from https://www.etsglobal.org/content/download/890/ 13127/version/2/file/TOEIC+CEFR+Mapping+Flyer-MAR338LR.pdf

Promnits-Hayashi, L. (2011). A learning success story using Facebook. Studies in Self-Access Learning Journal 2(4), 309-316.

Salaway, G, Caruso, J. B, \&Nelson, M. R. (2008). The ECAR study of undergraduate students and information technology. Boulder, Colorado: Educause.

Sari, M. (2014). The Use of Facebook in Blended Course in Teacher Training College. Al Ta'lim Journal, 21 (2), 145-153. 
Singh, H., and Reed, C. (2001). A white paper: Achieving success with blended learning. Los Angeles: Centra Software.

Stoltenkamp, J., Kabaka, N., \&Braaf, M. (2014). Support interventions during a blended course for teacher-educators from urban and rural settings. Creative Education, 5, 924-935. Retrieved December 11, 2014 from http://dx.doi.org/10.4236/ce.2014.511105

TOEIC Equivalence Tables. (n.d). Retrieved December 1, 2014 from http://www.nelson-aviation.co.nz/ ${ }^{\sim}$ downloads/TOEIC_Equiva lence_Tables.pdf

Valiathan, P. (2002). Blended learning models. Learning Circuits. Retrieved December 12, 2014 from http//www.learningcircuits.org/2002/ aug2002/valiathan.html

Warnecke E, Pearson S. (2011). Medical students' perceptions of using elearning to enhance the acquisition of consulting skills (SE Med Ed). Australasian Medical Journal, 4, 6: 300-307. Retrieved January 16, 2015 from http//dx.doi.org/10.4066/AMJ.2011.736

Yamada, M. (2009). The role of-social presence in learner-centered communicative language learning using synchronous computermediated communication: Experimental study. Computers $\mathcal{E}$ Education, 5 (2), 820-833. 